\author{
Marquette University \\ e-Publications@Marquette
}

8-2006

\title{
Nanostructured Layered Copper Hydroxy Dodecyl Sulfate: A Potential Fire Retardant for Poly(vinyl Ester) (PVE)
}

\author{
Everson Kandare \\ Marquette University \\ Grace Chigwada \\ Marquette University \\ Dongyan Wang \\ Cornell University \\ Charles A. Wilkie \\ Marquette University, charles.wilkie@marquette.edu \\ Jeanne Hossenlopp \\ Marquette University, jeanne.hossenlopp@marquette.edu
}

Follow this and additional works at: https://epublications.marquette.edu/chem_fac

Part of the Chemistry Commons

\section{Recommended Citation}

Kandare, Everson; Chigwada, Grace; Wang, Dongyan; Wilkie, Charles A.; and Hossenlopp, Jeanne, "Nanostructured Layered Copper Hydroxy Dodecyl Sulfate: A Potential Fire Retardant for Poly(vinyl Ester) (PVE)" (2006). Chemistry Faculty Research and Publications. 7.

https://epublications.marquette.edu/chem_fac/7 


\title{
Nanostructured Layered Copper Hydroxy Dodecyl Sulfate: A Potential Fire Retardant for Poly(vinyl Ester) (PVE)
}

\author{
Everson Kandare \\ Department of Chemistry, Marquette University \\ Milwaukee, WI \\ Grace Chigwada \\ Department of Chemistry, Marquette University \\ Milwaukee, WI
}

\section{Dongyan Wang}

Department of Materials Science and Engineering, Cornell

University

416 Bard Hall, Ithaca, NY

Charles A. Wilkie

Department of Chemistry, Marquette University

Milwaukee, WI

Jeanne M. Hossenlopp

Department of Chemistry, Marquette University

Milwaukee, WI 
NOT THE PUBLISHED VERSION; this is the author's final, peer-reviewed manuscript. The published version may be accessed by following the link in the citation at the bottom of the page.

\begin{abstract}
:
Composites of poly(vinyl ester) (PVE) with copper hydroxy dodecyl sulfate (CHDS) were prepared by thermal curing. The efficiency of the additive, CHDS, in reducing flammability is demonstrated via cone calorimetry and thermogravimetric analysis (TGA). The addition of $1-10 \%$ by mass of the CHDS additive resulted in significant increments in char formation ( 4-11\%) from thermogravimetric analysis (TGA). Incorporation of the CHDS into the polymer matrix at these low concentrations leads to substantial reductions in the total heat release $(\sim 20-30 \%)$ but no significant change in the peak heat release rate. The composite materials generally ignite more quickly, however, the flame extinguishes faster for the composites relative to the virgin polymer. X-ray diffraction (XRD) and infrared spectroscopic analyses of the residues collected at various stages during thermal decomposition of the composites, suggest the participation of copper-containing species in promoting enhanced thermal stability of PVE.
\end{abstract}

Keywords: Poly(vinyl ester), Layered hydroxy salt, Nanocomposites, Thermal stability, Fire retardancy.

\title{
1. Introduction
}

Thermal stability of polymers has been enhanced by blending virgin polymers with additives such as particulate inorganic oxides, like alumina trihydrate $(\mathrm{ATH})$ and magnesium hydroxide $\left(\mathrm{Mg}(\mathrm{OH})_{2}\right)$ [1] and [2]. However, the disadvantage of $\mathrm{ATH}$ and $\mathrm{Mg}(\mathrm{OH})_{2}$ is that they are most effective at very high loadings, about $65 \%$, which can have detrimental effects on the mechanical properties of the composite. Halogenated polyester resins have also been used to reduce flammability, but the potential toxicity of the evolved products during combustion has led to a reduction in the use of these resins [3] and [4]. Halogen-free flame-retardants, such as phosphoruscontaining monomers or additives, have also been investigated as potential thermal stabilizers [3], [5], [6], [7] and [8].

Polymer/clay nanocomposites have been shown to provide enhancements in physical properties of polymers such as increased tensile strength, tensile modulus, flexural strength, thermal stability, and corrosion protection owing to their structural morphology [8], [9], [10], [11], [12], [13], [14], [15] and [16]. Recently several classes of synthetic inorganic/organic compounds structurally similar to natural smectite clays have emerged as potential fire retardants [17], [18],

Polymer Degradation and Stability, Vol. 91, No. 8 (August 2006): pg. 1781-1790. DOI. This article is @ Elsevier and permission has been granted for this version to appear in e-Publications@Marquette. Elsevier does not grant permission for this article to be further copied/distributed or hosted elsewhere without the express permission from Elsevier. 
[19], [20], [21] and [22]. These include layered double hydroxides (LDHs), hydroxy double salts (HDSs), and layered hydroxy salts (LHSs), all containing positively charged metal hydroxyl layers with negatively charged anions contained in nanodimensional galleries. The ability to vary the identities of metals and interlayer anions provides design parameters that can be tuned to optimize additive's effectiveness.

Previous work has shown a significant reduction ( 20-30\%) in total heat release (THR) using cone calorimetry when coppercontaining hybrid inorganic/organic layered compounds, copper hydroxy methacrylate (CHM) and zinc/copper hydroxy double salts were used with polystyrene (PS) and poly (methyl methacrylate) (PMMA) [21], [22] and [23]. In the work reported herein, an LHS additive, copper hydroxy dodecyl sulfate (CHDS) is added to PVE to explore its potential utility as a fire retardant. Analysis of residues by $X$-ray diffraction (XRD) and Fourier transform infrared (FTIR) spectroscopy provides evidence of the role of chemical effects, due to the presence of copper, in stabilizing the composite.

\section{Experimental}

The chemicals used in this study, vinyl ester resin, bisphenolA/novalac epoxy, mass fraction of 67\% in styrene [Derakane 441-400] (Ashland Chemical Company); the initiator, 2-butanone peroxide [BuPO]; cobalt naphthenate catalyst [CoNp] (Aldrich Chemical Co.); sodium dodecyl sulfate (75.0\%) [SDS]; FTIR grade-potassium bromide [KBr] (Alfa Aesar); hydrated copper nitrate (98.9\%) $\left[\mathrm{Cu}\left(\mathrm{NO}_{3}\right)_{2} \cdot 2 \frac{1}{2} \mathrm{H}_{2} \mathrm{O}\right]$ (Fisher Scientific Company); and aqueous ammonium $\left[\mathrm{NH}_{4} \mathrm{OH}\right]$ (EM Science, Merck), were used as received.

A layered hydroxy salt (LHS), copper hydroxy nitrate, $\mathrm{Cu}_{2}(\mathrm{OH})_{3} \mathrm{NO}_{3}(\mathrm{CHN})$, was prepared via a standard literature method [24]. Copper (II) nitrate (100 g; $0.430 \mathrm{~mol})$ was added to $1 \mathrm{~L}$ of distilled water and the $\mathrm{pH}$ of the resultant solution adjusted to $8.0 \pm 0.1$ by the addition of aqueous ammonia. The dispersion was aged for $24 \mathrm{~h}$ after which the precipitate was filtered off, washed, and dried. Dodecyl sulfate anions were exchanged for the $\mathrm{NO}_{3}{ }^{-}$anions in $\mathrm{CHN}$ by mixing the dried $\mathrm{CHN}$ precursor material with $0.2 \mathrm{M}$ solution of sodium dodecyl sulfate. In the anion exchange process, $10 \mathrm{~g}$ of $\mathrm{CHN}$

Polymer Degradation and Stability, Vol. 91, No. 8 (August 2006): pg. 1781-1790. DOI. This article is (C) Elsevier and permission has been granted for this version to appear in e-Publications@Marquette. Elsevier does not grant permission for this article to be further copied/distributed or hosted elsewhere without the express permission from Elsevier. 
was mixed with $500 \mathrm{~mL}$ of the exchange solution and frequently shaken for $48 \mathrm{~h}$. The clear supernatant was decanted and replaced with a fresh solution of SDS for an additional $48 \mathrm{~h}$, after which the exchanged product, copper hydroxy dodecyl sulfate, $\mathrm{Cu}_{2}(\mathrm{OH})_{3}\left(\mathrm{CH}_{3}\left(\mathrm{CH}_{2}\right)_{11} \mathrm{OSO}_{3}\right)$ (CHDS), was recovered by filtration, washed, and dried.

Vinyl ester composites containing CHDS were prepared at room temperature by mixing the vinyl ester resin and fire retardant using a mechanical stirrer for $3 \mathrm{~h}$. The initiator, BuPO (1.3\%), was then added and the mixture stirred for a few minutes, followed by the addition of the catalyst, CoNP $(0.3 \%)$, and stirring continued for a few minutes to achieve homogeneity. Pure PVE was loaded to afford $n \%$ fraction of the additive within the polymer matrix, yielding composites identified as PVE/CHDS- $n$. Percent loadings were determined from the final mass of the composite, assuming no loss of the LHS during the preparation process. Approximately $30 \mathrm{~g}$ samples were rapidly transferred to preformed $10 \mathrm{~cm} \times 10 \mathrm{~cm} \times 3 \mathrm{~mm}$ aluminum dishes, making platelets of uniform thickness for cone analysis. Samples were allowed to cure overnight at room temperature and then post-cured at $80^{\circ} \mathrm{C}$ for $12 \mathrm{~h}$.

X-ray diffraction (XRD) patterns of the synthesized layered materials were obtained from a 2 circle Rikagu powder diffractometer operating in parafocusing Bragg-Bretano configuration, with a $1 / 2^{\circ}$ divergence slit, $1 / 2^{\circ}$ scatter slit, $0.15 \mathrm{~mm}$ receiving slit, $0.15 \mathrm{~mm}$ monochromator receiving slit using $\mathrm{Cu} \mathrm{Ka}(\lambda=1.54 \AA)$ radiation source operated at $50 \mathrm{kV}$ and $20 \mathrm{~mA}$. Data acquisition was performed in $2 \theta$ steps of $0.036^{\circ}$ per $20 \mathrm{~s}$ for the additive and at $0.072^{\circ}$ per $10 \mathrm{~s}$ for the composites. Powdered CHDS and residues from TGA and cone were mounted on quartz slides using 10\% (v/v) GE 7031 epoxy in ethanol after it was found that the epoxy did not perturb the observed peak patterns. Polymer composite samples were poured onto aluminum foil to make approximately $1 \mathrm{~mm}$ thick platelets, which were then cured in the same manner as samples for cone calorimetry. The resultant platelets were then mounted onto vertically oriented sample holders for XRD analysis. XRD peaks used to determine $d$-spacing were fit to pseudo-Voight functions stripping off the $\mathrm{Cu} \mathrm{Ka}$ contribution using XFIT [25]. Basal spacings of the synthesized clays and polymer composites were obtained using Bragg's equation; $\lambda=2 d \sin \theta$, averaging $00 /(I=1-3)$ reflections where possible. Assignments of

Polymer Degradation and Stability, Vol. 91, No. 8 (August 2006): pg. 1781-1790. DOI. This article is (C) Elsevier and permission has been granted for this version to appear in e-Publications@Marquette. Elsevier does not grant permission for this article to be further copied/distributed or hosted elsewhere without the express permission from Elsevier. 
phases of known copper-containing species were made using the powder diffraction database [26].

Fourier transform infrared (FTIR) spectra of the solid materials and composites were obtained using the $\mathrm{KBr}$ method on a Nicolet Magna-IR 560 spectrometer operated at $1 \mathrm{~cm}^{-1}$ resolution in the 400$4000 \mathrm{~cm}^{-1}$ region. Thermogravimetric analysis (TGA) and differential thermal analysis (DTA) were performed on an SDT 2960 simultaneous DTA-TGA instrument from $50-650{ }^{\circ} \mathrm{C}$ in $\mathrm{N}_{2}$ using a ramp rate of $20^{\circ} \mathrm{C} / \mathrm{min}$ with samples sizes in the range of $21 \pm 1 \mathrm{mg}$. All TGA experiments were done in triplicate; the reproducibility in the amount of nonvolatile residue is $\pm 2 \%$. Samples were analyzed by cone calorimetry on an Atlas Cone 2 instrument at an incident flux of $35 \mathrm{~kW} / \mathrm{m}^{2}$ with a cone shaped heater; the spark was continuous until the sample ignited. All samples were run in triplicate and the average value, with standard deviation, is reported; results from cone calorimeter are generally considered to be reproducible upto $\pm 10 \%$ [27]. Bright field transmission electron microscopy (TEM) images were collected at $60 \mathrm{kV}$ using a Zeiss $10 \mathrm{c}$ electron microscope.

\section{Results and discussion}

Fig. 1 shows the chemical structures of bisphenol-A and novalac epoxy vinyl ester resins. Radicals generated by the decomposition of the initiator, BuPO, initiate radical polymerization. Since the novalac epoxy vinyl resin has several pendant polymerizable vinyl containing groups, the resultant PVE will be highly cross-linked. X-ray diffraction (XRD) is commonly used to characterize the interlayer spacing of layered inorganic/organic hybrids. Fig. 2 shows the powder X-ray diffraction pattern of the layered hydroxy dodecyl sulfate, CHDS, additive. The samples were partially exchanged as evident from reflections due to the precursor, copper hydroxy nitrate (CHN) (PDF\# 14-687) [26] which are marked with solid triangles. The structure of $\mathrm{CHN}$ is shown in Fig. 3a. Two distinct phases of the exchanged product, marked with asterisks and solid circles are observed (Fig. 2). The average basal spacing, $d$, for the phase marked with solid circles was found to be $25.9 \pm 0.9 \AA$. This suggests that the dodecyl sulfate (DS) anions are arranged perpendicular to the hydroxylated metal sheets forming a monolayer array within the gallery space. The sulfate ends of the DS are bound to the positively charged LHS layers in an

Polymer Degradation and Stability, Vol. 91, No. 8 (August 2006): pg. 1781-1790. DOI. This article is (C) Elsevier and permission has been granted for this version to appear in e-Publications@Marquette. Elsevier does not grant permission for this article to be further copied/distributed or hosted elsewhere without the express permission from Elsevier. 
interdigitated fashion, maximizing the van der Waals attraction [28] as shown in Fig. 3b. Several researchers have reported similar results with layered double hydroxides (LDHs), which are inorganic/organic layered hybrids resembling the LHSs [28], [29] and [30]. The second LHS-DS phase, marked with asterisks in Fig. 2, was calculated using an average of $00 /(I=1$ and 2 ) reflections to have a basal spacing, $d$, of $39.2 \pm 0.2 \AA$, consistent with the DS anions arranged either in a partially interdigitated bilayer or tilted in such a way to have little or no overlap [28]. Fig. 3c shows a bilayer arrangement with DS anions arranged in a perpendicular fashion to hydroxy layers with no overlap. This phase will be designated as the bilayer orientation.

Formation of two new exchanged phases is not uncommon for the anionic exchange in layered hybrid inorganic/organic copper (II) compounds [31] and [32]. This has been attributed to the coexistence of both gauche and trans arrangements of the exchanging anions in the interlayer spacing or possibly to the presence of phases with different degrees of hydration. In the case of dodecyl sulfate, it is most likely that the differences in orientation of the alkyl chains lead to the formation of the two phases. The overall extent of anion exchange has been found to be dependent on the chain length. In the case of zinc copper acetate hydroxy double salt, exchange with octanoate at room temperature proceeded to completion while shorter exchange anions such as butyrate did not completely exchange [33]. This is consistent with a thermodynamic stabilization effect for the longer alkyl chains [34]. Park and Lee have recently reported [35] alkyl chain length effects in $\mathrm{CHN}$ exchanged with sulfonates. In the case of $\mathrm{C}_{n} \mathrm{H}_{2 n+1} \mathrm{SO}_{3}{ }^{-}$ anions with $n=12-18$, incomplete exchanges were observed while those with $n=6-10$ proceeded to complete exchange, an effect attributed to the weak coordinating power of the sulfonate.

In the inset in Fig. 2, the XRD patterns of the polymer/CHDS composites at a range of loadings from 1 to $10 \%$ are shown. Features due to the additive are evident at higher loadings. All phases from the CHDS except the one with a $39.2 \AA d$ spacing are retained in the composites, without displacement from their original $2 \theta$ positions. This suggests that no polymer chains and/or monomers were intercalated into the gallery spaces of either the $\mathrm{CHN}$ or the monolayer phase of CHDS ( $d=25.9 \AA$ ). However, the disappearance of the CHDS reflections at $2 \theta$ values of 2.3 and $4.5^{\circ}$ (bilayer phase; $d=39.2 \AA$ )

Polymer Degradation and Stability, Vol. 91, No. 8 (August 2006): pg. 1781-1790. DOI. This article is @ Elsevier and permission has been granted for this version to appear in e-Publications@Marquette. Elsevier does not grant permission for this article to be further copied/distributed or hosted elsewhere without the express permission from Elsevier. 
from the XRD patterns of the composites even at $10 \%$ loadings suggests the formation of either an exfoliated and/or intercalated nanocomposite. Exfoliation would lead to a disordered arrangement of LHS layers, hence the disappearance of reflections at $2 \theta$ values of 2.3 and $4.5^{\circ}$. Intercalation of polymer chains could result in a very large $d$ spacing corresponding to very low $2 \theta$ values, which would be beyond the detection limit of the wide-angle $X$-ray diffraction apparatus used in this study. The possibility of free spaces within the interlayer domain of the bilayer phase suggests that monomeric units and/or polymer chains can be incorporated hence the possibility of exfoliation and/or intercalation.

$\mathrm{XRD}$ alone can, in some cases, demonstrates the formation of intercalated nanocomposites, but cannot distinguish between exfoliation and immiscibility. Transmission electron microscopy (TEM) becomes an important complementary tool to investigate the morphology of the composites. Fig. 4 shows TEM images for the $5 \%$ loaded poly(vinyl ester) sample, PVE/CHDS-5, at both low and high magnifications. The low magnification images provide information about the nano-dispersion while the high magnification images tell whether exfoliation and/or intercalation has been achieved. The low magnification TEM image shown on the left in Fig. 4 is consistent with formation of a microcomposite; darker portions perceived as metal hydroxide sheets are separated by more than $10^{4} \AA$. Regularly spaced stripes running diagonally across the image are an artifact introduced by knife-edges during sample preparation. The high magnification image shown on the right in Fig. 4 does not show clear evidence of either exfoliation or intercalation, consistent with the presence of the monolayer CHDS and CHN phases in PVE/CHDS-5.

Fig. 5A shows the thermogravimetric analysis (TGA) curves for pure PVE and its composites at 1, 5, and $10 \%$ loading. Fig. 5B shows the derivatives of these curves. The TGA for pure PVE, in Fig. 5A, consists primarily of a single step with a small low temperature shoulder that is more obvious in the derivative curve shown in Fig. 5B. Similar trends are observed for the 1 and $5 \%$ loaded composites, but the temperatures of maximum degradation are slightly lower than for the pure PVE. However, the $10 \%$ loaded sample shows a different thermal behavior with two distinct degradation steps, having maximum degradation rates occurring at 340 and $430{ }^{\circ} \mathrm{C}$,

Polymer Degradation and Stability, Vol. 91, No. 8 (August 2006): pg. 1781-1790. DOI. This article is (C) Elsevier and permission has been granted for this version to appear in e-Publications@Marquette. Elsevier does not grant permission for this article to be further copied/distributed or hosted elsewhere without the express permission from Elsevier. 
respectively. The earlier mass loss may be due to the loss of the additive and/or monomeric units remaining after the curing process.

The initial degradation temperatures, measured by the temperature at which $10 \%$ weight loss occurs, $T_{10}$, are presented in Table 1 and are useful for assessing low temperature thermal stability of composites. $T_{10}$ values decrease with an increase in the amount of the additive. This is clearly seen from the mass difference curves of the composites relative to the pure PVE (remaining mass \% of PVE composites minus remaining mass \% of pure PVE at the same temperature), shown in Fig. 6A. For all three composites considered here, a destabilization behavior is seen in the temperature range of $100-450{ }^{\circ} \mathrm{C}$ (peaking at 435,420 , and $400{ }^{\circ} \mathrm{C}$ for 1,5 , and $10 \%$ loadings, respectively). The samples loaded at 1 and $5 \%$ show small and comparable mass losses in this temperature range while a significant destabilization effect is noted for a $10 \%$ loaded sample. The ease with which highly loaded PVE samples degrade at lower temperatures suggests that the additive may have a negative effect on the cross-linking density of the cured composite. The presence of CHDS was also observed to lead to an increase in the time required for the polymer composite to set. CHDS may therefore decrease the curing reactivity of the vinyl resins, leading to the formation of long polymer chains with fewer cross-links and hence low thermal stability in the lower temperature regime.

At $450{ }^{\circ} \mathrm{C}$ and above, the mass loss difference curves shown in Fig. 6A are positive for all three composites compared. This suggests a stabilizing behavior due to the presence of additives, possibly catalytic formation of cross-linked char and less volatile products at these high temperatures. The temperature at which $50 \%$ mass loss occurs, $T_{50}$, is slightly lower (small negative $\Delta T_{50}$ values) for the composites compared to the virgin polymer as shown in Table 1 . These reductions in the $T_{50}$ values are relatively small in comparison to phosphoruscontaining PVE nanocomposites [8].

The char \% as measured by the amount of residue remaining at $650{ }^{\circ} \mathrm{C}$ increased with percent additive. Also shown in Table 1 , is the expected char \% if the residues were additive, based on the residue obtained from pure PVE and CHDS. The fact that the observed residue is higher than the calculated residue demonstrates the effectiveness of the additive, CHDS, in char formation. Taking into account the thermal

Polymer Degradation and Stability, Vol. 91, No. 8 (August 2006): pg. 1781-1790. DOI. This article is C) Elsevier and permission has been granted for this version to appear in e-Publications@Marquette. Elsevier does not grant permission for this article to be further copied/distributed or hosted elsewhere without the express permission from Elsevier. 
stability at low temperatures and also the amount of char remaining at the end of the combustion process, the $5 \%$ loaded composite provides the best stabilization of the formulations tested here.

Fig. 6B shows differential thermogravimetric analysis (DTA) curves for pure PVE and its 1, 5, and $10 \%$ loaded composites. The DTA profile of the pure polymer shows a pronounced endothermic step at $450{ }^{\circ} \mathrm{C}$ corresponding to its maximum degradation rate temperature. The DTA curves for the composites show significantly different patterns. Pronounced exotherms are seen in the region of $250-420{ }^{\circ} \mathrm{C}$ for the composites and may be attributed to the thermo-degradation of the dodecyl sulfate. The endothermic process at around $450{ }^{\circ} \mathrm{C}$ decreases in magnitude with an increase in the percent additive. This suggests that even though there is significant mass loss at lower temperatures for the composites, there is a compensatory stabilization process at $450{ }^{\circ} \mathrm{C}$ which happens to be the maximum degradation rate temperature for pure PVE. The endothermic peak at around $450{ }^{\circ} \mathrm{C}$ is shifted to slightly lower temperatures for the composites with an increase in percent additive consistent with the slight reduction in degradation temperatures as noted earlier.

Effects of the additive on the flammability of PVE were measured using cone calorimetry; the parameters available include the heat release rate and especially its peak value, the peak heat release rate (PHRR); total heat release (THR); time to self-sustained combustion (TSC); average mass loss rate (AMLR); and char yield (CY). Ideally, a decrease in the peak heat release rate, total heat released and the mass loss rate is desired along with an increase in char, time to sustained combustion and to reach the PHRR value. The heat release rate (HRR) as a function of time for pure PVE and its composites ( 1,5 , and $10 \%$ loadings) at a flux of $35 \mathrm{~kW} / \mathrm{m}^{2}$ is shown in Fig. 7. The addition of CHDS lowers the time to sustained combustion of the composites relative to the virgin polymer but the HRR curves for the composites show that the evolution of heat is spread over a narrow range of the combustion time. Even though the polymer composites start to burn earlier, they extinguish much faster than the pristine PVE. There is very little or no reduction in PHRR for all the modified PVE composites as shown in Fig. 7. However, PHRR percent reductions of $18 \pm 12$ and $29 \pm 6$ were observed for the 3 and $7 \%$ loaded composites. There is no obvious correlation between the

Polymer Degradation and Stability, Vol. 91, No. 8 (August 2006): pg. 1781-1790. DOI. This article is (C) Elsevier and permission has been granted for this version to appear in e-Publications@ Marquette. Elsevier does not grant permission for this article to be further copied/distributed or hosted elsewhere without the express permission from Elsevier. 
reduction in PHRR and the percent additive. Table 2 gives a summary of the results obtained for PVE and its composites with different additive loadings.

Significant percent reductions, in the $20-30 \%$ range, in the total heat released are observed with these low additive loading percentages. This is not uncommon, as PVE composites containing phosphorus-based fire retardants have been shown to have lower THRs but a wider heat release distribution profile [8]. Inorganic/organic modifiers burn out at low temperature, producing inorganic metal oxide residues that might slow or inhibit thermal degradation of the composites. The presence of the inorganic/organic modifiers in the PVE composites may provide heat sinks during combustion, perhaps via the formation of a physical barrier (crosslinked char) that prevents diffusion of radicals and improves the thermal stability of the polymer.

Expected percent reductions in total heat release (THR) were calculated based on cumulative THR values assuming that there is no interaction between the polymer and the additives. Fig. 8 shows plots of the expected reductions in THR, shown as open circles, and the experimentally observed values shown as solid circles. The experimentally obtained reductions in THR are significantly larger than the calculated values suggesting that THR reductions are not simply a result of replacing some fraction of PVE $\left(T H R=79 \mathrm{MJ} / \mathrm{m}^{2}\right)$ with an equal amount of the additive, CHDS, which has a lower THR value of $51 \mathrm{MJ} / \mathrm{m}^{2}$ for the same mass (30 g) sample. This is clear evidence that the addition of the layered hydroxy salt, CHDS, is effective in reducing the flammability of the PVE. The improvement in fire retardancy is shown by the reduction in the THR and the increase in the char remaining after complete combustion as shown in Table 2.

Differences in copper oxidation states in cone calorimetric residues were observed for PMMA composites made with $\mathrm{CHM}$ and a zinc/copper methacrylate HDS [21]. In order to investigate the evolution of copper oxidation states, the composite, PVE/CHDS-10 was heated in the TGA at $20^{\circ} \mathrm{C} / \mathrm{min}$ and in the cone calorimeter and the resulting residues were analyzed by XRD; patterns are shown in Fig. 9. The XRD pattern of PVE/CHDS-10 from TGA at $250{ }^{\circ} \mathrm{C}$ reveals the presence of the $\mathrm{CHN}$ phase and $\mathrm{Cu}_{2} \mathrm{O}$ (PDF\# 35-1091) [26]. The monolayer CHDS phase is not evident from XRD patterns at this

Polymer Degradation and Stability, Vol. 91, No. 8 (August 2006): pg. 1781-1790. DOI. This article is (C) Elsevier and permission has been granted for this version to appear in e-Publications@Marquette. Elsevier does not grant permission for this article to be further copied/distributed or hosted elsewhere without the express permission from Elsevier. 
temperature, suggesting its collapse and/or existence in an amorphous state. $\mathrm{Cu}_{2} \mathrm{O}$ and metallic copper (PDF\# 4-836) [26] are seen in the XRD pattern of the residue collected at $300^{\circ} \mathrm{C}$. Of particular interest is the disappearance of the $\mathrm{Cu}$ (I) oxide at $350^{\circ} \mathrm{C}$ with the formation of metallic copper and a second phase marked with crosses that could not be identified. Disproportionation of $\mathrm{Cu}$ (I) may lead to the formation of metallic copper, $\mathrm{Cu}(0)$ and $\mathrm{Cu}$ (II) as illustrated by the equation; $2 \mathrm{Cu}(\mathrm{I}) \rightarrow \mathrm{Cu}(0)+\mathrm{Cu}(\mathrm{II})$. This suggests that the unidentified phase may be a $\mathrm{Cu}$ (II) containing compound, however, further work is necessary to assign this phase.

Metallic copper (Cu), generated from copper (I) salts ( $\mathrm{CuCl}$, $\mathrm{CuBr}$, and $\mathrm{CuI}$ ) and $\mathrm{Cu}$ (II) complexes during pyrolysis, has been reported [36] and [37] to have a stabilizing effect on the thermal degradation of poly(vinyl chloride) (PVC), by catalyzing intermolecular cross-linking of conjugated polyenes produced during the initial stages of degradation. Otherwise, these polyenes could undergo cyclization reactions leading to the formation of benzene and other aromatics, which would burn to produce heat and smoke. In the case of PVE, an analogous reductive coupling reaction that promotes char formation could occur following the abstraction of pendant hydroxy groups from the PVE chains by reduced copper species. Cu (II) readily reduces to $\mathrm{Cu}(\mathrm{I})$ or $\mathrm{Cu}(0)$ [38] and metallic copper is observed in the XRD pattern of TGA residues for PVE/CHDS-10 at 300, 350, 400, and $450{ }^{\circ} \mathrm{C}$. However, further work is required to elucidate the role of copper-containing species in the stabilization of the polymer.

The possible reductive coupling via $\mathrm{OH}$ abstraction to form cross-linked polymer would result in the formation of $\mathrm{Cu}-\mathrm{OH}$ species. Fig. 10 shows the Fourier transform infrared (FTIR) of the TGA residue of PVE/CHDS-10 at various temperatures. A sharp, intense absorption band observed around $3740 \mathrm{~cm}^{-1}$ (for traces at 350 and $400{ }^{\circ} \mathrm{C}$ ) is consistent with the presence of non-hydrogen bonded $\mathrm{Cu}-\mathrm{OH}$ groups [39]. There is no evidence of an increase in the $\mathrm{C}=\mathrm{C}$ absorption band at around $1600 \mathrm{~cm}^{-1}$ (between 350 and $450{ }^{\circ} \mathrm{C}$ ) suggesting that reductive coupling prevails over dehydration. Pike et al. [36] reported that low-valent metal additives prevent cracking of hydrocarbon char at high temperature, suggesting that less volatile molecules are produced reducing smoke while increasing the remaining char. This is consistent with reduction in the amount of smoke as seen from cone

Polymer Degradation and Stability, Vol. 91, No. 8 (August 2006): pg. 1781-1790. DOI. This article is C) Elsevier and permission has been granted for this version to appear in e-Publications@Marquette. Elsevier does not grant permission for this article to be further copied/distributed or hosted elsewhere without the express permission from Elsevier. 
calorimetry. The XRD patterns of the TGA residue at the indicated temperatures for PVE/CHDS-10 do not show any evidence of polycrystalline $\mathrm{Cu}(\mathrm{OH})_{2}$, the expected product of hydroxyl abstraction from polymer chains, suggesting that this intermediate may only exist in an amorphous form.

The presence of $\mathrm{Cu}$ in the polymeric matrix during combustion may thus serve to stabilize the composite materials, consistent with the enhanced residue from TGA and cone. Most likely these LHSs act as flame-retardants through three modes of action: (a) dilution of combustion atmosphere by non-combustible gases $\left(\mathrm{H}_{2} \mathrm{O}\right.$ and $\left.\mathrm{CO}_{2}\right)$ generated from the thermal degradation of the additives; (b) the inorganic combustion products may act as a physical barrier (crosslinked char) reducing diffusion of combustible matter (mass transport) and/or energy transfer, hence improving flame retardation; and (c) the metal species participate in coupling reactions preventing the generation of small molecules that act as fuels.

\section{Conclusion}

Copper hydroxy dodecyl sulfate (CHDS) has been used as an additive to provide thermal stability to PVE. In TGA experiments, only minor decrease in $T_{50}$ is observed with this additive, in contrast to the more significant destabilization observed with phosphorus-containing additives [8] and [40]. Addition of small amounts of the CHDS (1$10 \%$ ) to pure PVE results in a significant reduction in the total heat release (THR) from cone calorimetry (20-30\%) and $\sim 160 \%$ increase in the amount of char remaining from TGA experiments at $650{ }^{\circ} \mathrm{C}$.

Similar increments ( $200 \%)$ in the char remaining after combustion in a cone calorimetry are observed, suggesting significant retardation in flammability of the composites relative to pure PVE. However, there is no reduction in peak heat release rate (PHRR). The presence of reduced copper-containing species during the course of degradation of the composites may catalyze the formation of cross-linked char from reductive coupling reactions, resulting in effective thermal stabilization of these polymeric materials. Copper-based additives are thus very promising for the improvement of thermal stability and fire retardancy of PVE. Studies on possible synergistic effects between CHDS and conventional fire retardants will be the focus of a separate publication [40].

Polymer Degradation and Stability, Vol. 91, No. 8 (August 2006): pg. 1781-1790. DOI. This article is @ Elsevier and permission has been granted for this version to appear in e-Publications@Marquette. Elsevier does not grant permission for this article to be further copied/distributed or hosted elsewhere without the express permission from Elsevier. 
NOT THE PUBLISHED VERSION; this is the author's final, peer-reviewed manuscript. The published version may be accessed by following the link in the citation at the bottom of the page.

\section{Acknowledgements}

We thank the Office of Naval Research (CAW, Grant N00014-03-10172) for financial assistance and M. Bartelt and J. Collins for technical support of the X-ray diffractometer.

\section{References}

1. Weil ED, Kim HK. Flame retardant unsaturated resins-an overview and new developments. In: Eighth annual BCC conference on advances in flame retardancy of polymeric materials. Stamford, Connecticut; 1997.

2. Kicko-Walczak E. Polimery 1999;44:724.

3. Cusak PA, Heer MS, Monk AW. Polym Degrad Stab 1991;32:177.

4. Liang H, Asif A, Shi W. J Polym Sci Part A Polym Chem 2005;97:185.

5. Liang H, Shi W. Polym Degrad Stab 2004;84:525.

6. Wang X. In: Wilkie CA, Nelson GL, editors. Fire and polymers IV: materials and concepts for hazard prevention. ACS symposium series. Oxford University Press; 2006. p. 266-79.

7. Zheng X, Wilkie CA. Polym Degrad Stab 2003;81:539.

8. Chigwada G, Jash P, Jiang DD, Wilkie CA. Polym Degrad Stab 2005;89:85.

9. Alexandre M, Dubois P. Mater Sci Eng 2000;R28: 1.

10. Yeh J-M, Liou S-J, Lai C-Y, Wu P-C. Chem Mater 2001;13:1131.

11. Gu A, Liang G. Polym Degrad Stab 2003;80:383.

12. Zanetti M, Camino G, Canavese D, Morgan AB, Lamelas FJ, Wilkie CA. Chem Mater 2002;14:189.

13. Choi J, Harcup J, Yee AF, Zhu Q, Laine RM. J Am Chem Soc $2001 ; 123: 11420$.

14. Kornmann X, Thomann R, Mulhaupt R, Finter J, Berglund L. J Polym Sci Part A Polym Chem 2002;86:2643.

15. Devax E, Rochery M, Bourbigot S. Fire Mater 2002;26:149.

16. Kim D-S, Kim J-T, Woo W-B. J Appl Polym Sci 2005;96:1641.

17. Leroux F, Besse J. Chem Mater 2001;13:3507.

18. Bubniak GA, Schreiner WH, Mattoso N, Wypych F. Langmuir 2002; 18:5967.

Polymer Degradation and Stability, Vol. 91, No. 8 (August 2006): pg. 1781-1790. DOI. This article is (C) Elsevier and permission has been granted for this version to appear in e-Publications@Marquette. Elsevier does not grant permission for this article to be further copied/distributed or hosted elsewhere without the express permission from Elsevier. 
NOT THE PUBLISHED VERSION; this is the author's final, peer-reviewed manuscript. The published version may be accessed by following the link in the citation at the bottom of the page.

19. Messersmith BP, Stupp SI. Chem Mater 1995;7:454.

20. Chen W, Qu B. Chem Mater 2003;15:3208.

21. Kandare E, Hall D, Jiang DD, Hossenlopp JM. In: Wilkie CA, Nelson GL, editors. Fire and polymers IV: materials and concepts for hazard prevention. ACS symposium series. Oxford University Press; 2006. p. 131-43.

22. Kandare E, Deng H, Wang D, Hossenlopp JM. Polym Adv Technol, in press.

23. Kandare E, Hossenlopp JM. Adapting hydroxy double salts for polymer fire retardancy applications. In: Sixteenth annual BCC conference on advances in flame retardancy of polymeric materials. Stamford, Connecticut; 2005.

24. Tanaka H, Terada S. J Therm Anal 1993;39:1011.

25. Cheary RW, Coelho AA. Programs XFIT and FOURYA, deposited in CCP14. Warrington, England: Powder Diffraction Library, Engineering and Physical Sciences. Research Council, Daresbury Laboratory, <http://www.ccp14.ac.uk/tutorial/xfit-95/xfit.htm>; 1996.

26. Powder diffraction file alphabetical indexes. Inorganic phases. Swartmore, PA: JCPDS, International Centre for Diffraction Data; 1999.

27. Gilman JW, Kashiwagi T, Nyden M, Brown JET, Jackson CL, Lomakin S, et al. In: AI-Maliaka S, Golovoy A, Wilkie CA, editors. Chemistry and technology of polymer additives. London: Blackwell Science Ltd; 1999. p. 249-65.

28. Clearfield A, Kieke M, Kwan J, Colon JL, Wang RC. J Inclusion Phenom Mol Recognit Chem 1991;11:361.

29. Kopka H, Beneke K, Lagaly G. J Colloid Interface Sci 1988;123:427.

30. Drezdon MA. Inorg Chem 1988;27:4628.

31. Fujita W, Awaga K. Inorg Chern 1996;35:1915.

32. Fujita W, Laget V, Hornick C, Rabu P, Drillon M. Mater Chem 1999;9:169.

33. Kandare E, Hossenlopp JM. J Phys Chem B 2005; 109:8469.

34. Alberti G, Costantino U. Layered solids and their intercalation chemistry. In: Alberti G, Bein T, editors. Comprehensive supramolecular chemistry: two and three dimensional networks, vol. 7. Great Britain: Elsevier Sci. Ltd; 1996. p. 11.

Polymer Degradation and Stability, Vol. 91, No. 8 (August 2006): pg. 1781-1790. DOI. This article is (C) Elsevier and permission has been granted for this version to appear in e-Publications@Marquette. Elsevier does not grant permission for this article to be further copied/distributed or hosted elsewhere without the express permission from Elsevier. 
NOT THE PUBLISHED VERSION; this is the author's final, peer-reviewed manuscript. The published version may be accessed by following the link in the citation at the bottom of the page.

35. Park S-H, Lee EL. J Phys Chem B 2005; 109: 1118.

36. Pike RD, Starnes WH, Jeng JP, Bryant WS, Kourtesis P, Adams CW, et al. Macromolecules 1997;30:6957.

37. Starnes WH, Pike RD, Cole JR, Doyal AS, Kimlin EJ, Lee JT, et al. Polym Degrad Stab 2003;82:15.

38. Shriver DF, Atkins $\mathrm{P}$, Langford CH. Inorganic chemistry. 2nd ed. New York: Freeman; 1994. p. 295.

39. Masciocchi N, Corradi E, Sironi A, Moretti G, Minelli G, Porta P. J Solid State Chem 1997;131:252.

40. Kandare E, Chigwada G, Wang D, Wilkie CA, Hossenlopp JM. Polym Degrad Stab, in press.

\section{About the Authors}

Jeanne M. Hossenlopp : Department of Chemistry, Marquette University, P.O. Box 1881, Milwaukee, WI 53201-1881, USA

Tel.: +14142883537; fax: +14142887066 .

Email: jeanne.hossenlopp@mu.edu

\section{Appendix}

\section{Table 1}

TGA data for PVE composites

\begin{tabular}{|l|c|c|c|c|}
\hline \multicolumn{1}{|c|}{ Sample } & $\boldsymbol{T}_{10}\left({ }^{\circ} \mathrm{C}\right)$ & $\boldsymbol{T}_{\mathbf{5 0}}\left({ }^{\circ} \mathrm{C}\right)$ & $\Delta \boldsymbol{T}_{50}\left({ }^{\circ} \mathrm{C}\right)$ & Char $(\%)$ \\
\hline PVE & $410 \pm 0$ & $444 \pm 0$ & 0 & $7 \pm 0$ \\
\hline PVE/CHDS-1 & $385 \pm 6$ & $438 \pm 1$ & $-6 \pm 1$ & $11 \pm 1(8)$ \\
\hline PVE/CHDS-3 & $374 \pm 1$ & $439 \pm 0$ & $-5 \pm 0$ & $13 \pm 0(9)$ \\
\hline PVE/CHDS-5 & $385 \pm 1$ & $441 \pm 1$ & $-3 \pm 1$ & $13 \pm 0(10)$ \\
\hline PVE/CHDS-7 & $342 \pm 3$ & $441 \pm 1$ & $-3 \pm 1$ & $13 \pm 0(11)$ \\
\hline PVE/CHDS-10 & $284 \pm 6$ & $440 \pm 1$ & $-4 \pm 1$ & $18 \pm 2(12)$ \\
\hline
\end{tabular}

$T_{10}$, temperature at which $10 \%$ mass loss occurs; $T_{50}$, temperature at which $50 \%$ mass loss occurs; $\Delta T_{50}, T_{50}$ (composite) minus $T_{50}$ (pure PVE). Italicized entries are the expected char based on the residue obtained from pure PVE and CHDS samples.

Polymer Degradation and Stability, Vol. 91, No. 8 (August 2006): pg. 1781-1790. DOI. This article is (c) Elsevier and permission has been granted for this version to appear in e-Publications@Marquette. Elsevier does not grant permission for this article to be further copied/distributed or hosted elsewhere without the express permission from Elsevier. 
NOT THE PUBLISHED VERSION; this is the author's final, peer-reviewed manuscript. The published version may be accessed by following the link in the citation at the bottom of the page.

\section{Table 2}

Cone calorimetry data for PVE composites at $35 \mathrm{~kW} / \mathrm{m}^{2}$

\begin{tabular}{|c|c|c|c|c|c|c|c|}
\hline Sample & TSC (s) & PHRR (kW/m²) (\%red) & $t_{\text {PHRR }}(\mathbf{s})$ & THR $\left(\mathrm{MJ} / \mathrm{m}^{2}\right)$ (\%red) & AMLR $\left(g / s^{2}{ }^{2}\right)$ & CY (\%) & $\begin{array}{c}\text { ASEA } \\
\left(\mathrm{m}^{2} / \mathrm{kg}\right)\end{array}$ \\
\hline PVE & $65 \pm 9$ & $895 \pm 67$ & $137 \pm 7$ & $79 \pm 1$ & $27 \pm 1$ & $3.9 \pm 0.2$ & $1089 \pm 88$ \\
\hline PVE/CHDS-1 & $49 \pm 5$ & $953 \pm 49(-7)$ & $121 \pm 10$ & $63 \pm 1(19)$ & $30 \pm 1$ & $4.5 \pm 0.3$ & $1034 \pm 15$ \\
\hline PVE/CHDS-3 & $40 \pm 2$ & $731 \pm 80(18)$ & $101 \pm 14$ & $62 \pm 1(21)$ & $25 \pm 3$ & $5.5 \pm 0.7$ & $1107 \pm 41$ \\
\hline PVE/CHDS-5 & $28 \pm 6$ & $879 \pm 56(6)$ & $106 \pm 8$ & $64 \pm 1(18)$ & $28 \pm 1$ & $8.1 \pm 0.3$ & $1021 \pm 40$ \\
\hline PVE/CHDS-7 & $26 \pm 2$ & $631 \pm 57(29)$ & $101 \pm 8$ & $62 \pm 1(21)$ & $34 \pm 1$ & $8.5 \pm 0.0$ & $858 \pm 23$ \\
\hline PVE/CHDS-10 & $26 \pm 3$ & $853 \pm 18(5)$ & $56 \pm 3$ & $58 \pm 1(27)$ & $27 \pm 2$ & $11.8 \pm 0.2$ & $948 \pm 21$ \\
\hline
\end{tabular}

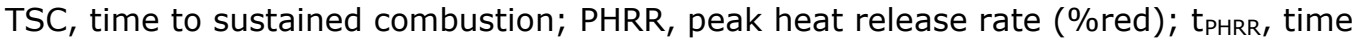
to peak heat release rate; THR, total heat release (\%red); AMLR, average mass loss rate; $\mathrm{CY}$, char \%; ASEA, average specific extinction area (a measure of smoke).

\section{Figure 1}

Chemical structures of bisphenol-A and novalac epoxy vinyl resins.<smiles>C=C(C)C(=O)OCC(O)COc1ccc(C(C)(C)c2ccc(OCC(O)COC(=O)C(=C)C)cc2)cc1</smiles><smiles>C=C(C)C(=O)OCC(O)COc1ccc(Cc2cccc(OCC(O)COC(=O)C(=C)C)c2)cc1</smiles>

Polymer Degradation and Stability, Vol. 91, No. 8 (August 2006): pg. 1781-1790. DOI. This article is @ Elsevier and permission has been granted for this version to appear in e-Publications@Marquette. Elsevier does not grant permission for this article to be further copied/distributed or hosted elsewhere without the express permission from Elsevier. 
NOT THE PUBLISHED VERSION; this is the author's final, peer-reviewed manuscript. The published version may be accessed by following the link in the citation at the bottom of the page.

\section{Figure 2}

XRD data for partially exchanged CHDS reveal the presence of two new phases; $(*)$ with basal spacing, $d=39.2 \AA$ and $(\bullet)$ with $d=25.9 \AA$. Reflections from the precursor, $\mathrm{CHN}$, are present $(\boldsymbol{\Lambda})$. The inset shows the XRD patterns of the PVE- $n$ composites at $n=1,3,5,7$, and 10\% loadings, labeled PVE/CHDS-1, PVE/CHDS-3, PVE/CHDS-5, PVE/CHDS-7, and PVE/CHDS-10, respectively, and also the XRD pattern of the partially exchanged CHDS, scaled by a factor of $1 / 4$. Data for the PVE composites are offset for clarity but not otherwise scaled.

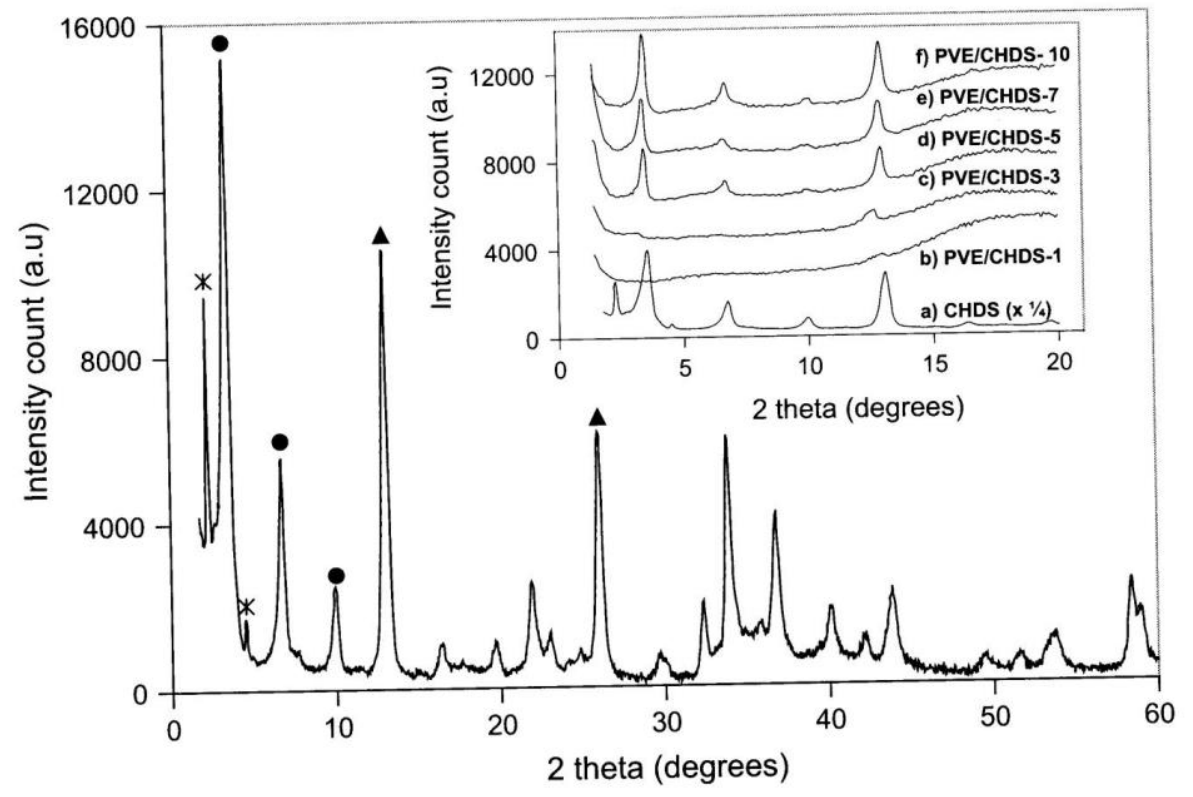

Polymer Degradation and Stability, Vol. 91, No. 8 (August 2006): pg. 1781-1790. DOI. This article is (C) Elsevier and permission has been granted for this version to appear in e-Publications@Marquette. Elsevier does not grant permission for this article to be further copied/distributed or hosted elsewhere without the express permission from Elsevier. 
NOT THE PUBLISHED VERSION; this is the author's final, peer-reviewed manuscript. The published version may be accessed by following the link in the citation at the bottom of the page.

\section{Figure 3}

Schematic representations of (a) the layered copper hydroxy nitrate (CHN); copper (grey), nitrogen (black), and $\mathrm{O} / \mathrm{OH}$ (white), (b) monolayer, and (c) bilayer phases of CHDS.

(a)

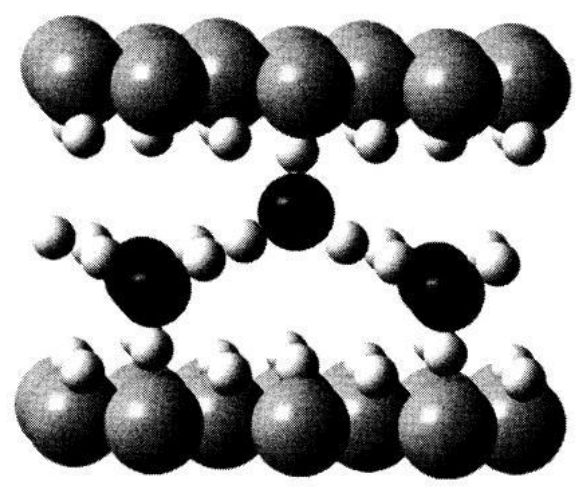

(b)

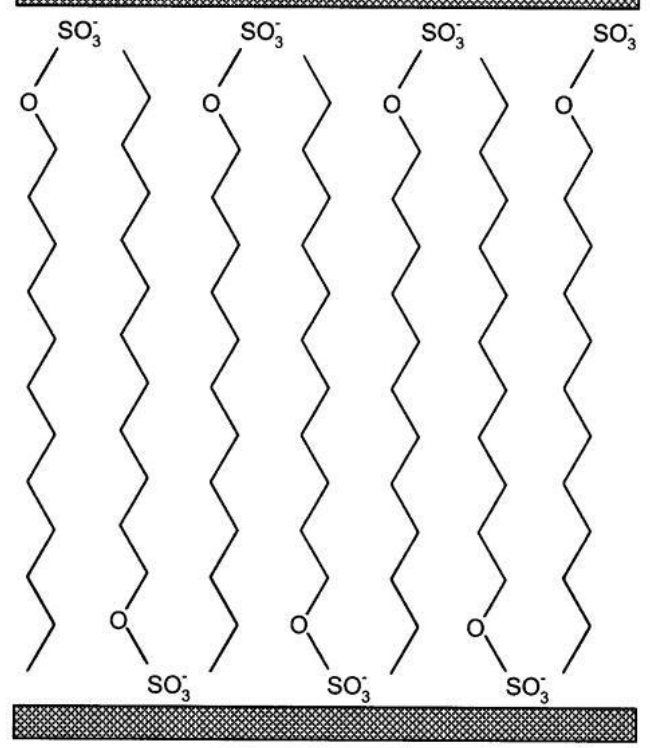

(c)

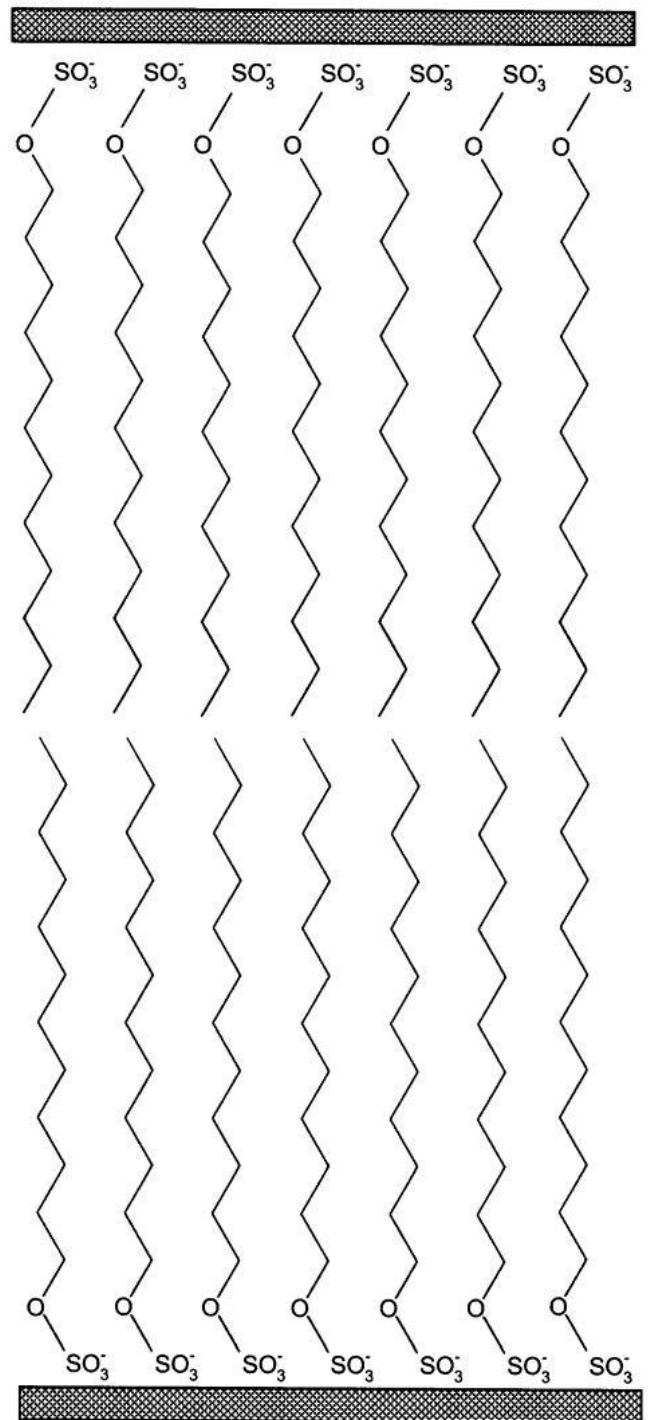

Polymer Degradation and Stability, Vol. 91, No. 8 (August 2006): pg. 1781-1790. DOI. This article is (C) Elsevier and permission has been granted for this version to appear in e-Publications@Marquette. Elsevier does not grant permission for this article to be further copied/distributed or hosted elsewhere without the express permission from Elsevier. 
NOT THE PUBLISHED VERSION; this is the author's final, peer-reviewed manuscript. The published version may be accessed by following the link in the citation at the bottom of the page.

\section{Figure 4}

TEM images at low (left) and high (right) magnifications for PVE/CHDS-5. For low magnification, the scale bar (bottom center) represents $500 \mathrm{~nm}$ while for high magnification, the scale bar (bottom center) represents $100 \mathrm{~nm}$. Regularly spaced stripes running diagonally across the image are an artifact due to sample preparation.
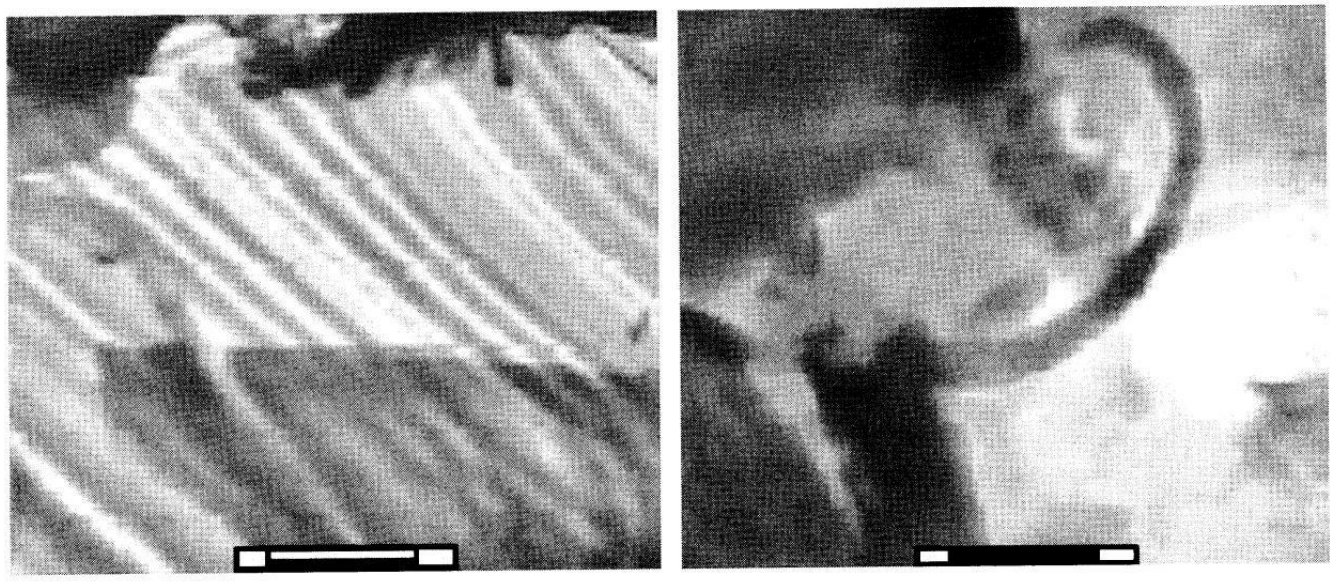

\section{Figure 5}

(A) TGA curves for pure PVE (dotted and dashed), PVE/CHDS-1 (solid), PVE/CHDS-5 (hatched), and PVE/CHDS-10 (bold). (B) DTG curves for PVE/CHDS-1 (solid), PVE/CHDS-5 (hatched), pure PVE (dotted and dashed), and PVE/CHDS-10 (bold). Derivatized mass losses are scaled by a factor of 100 .

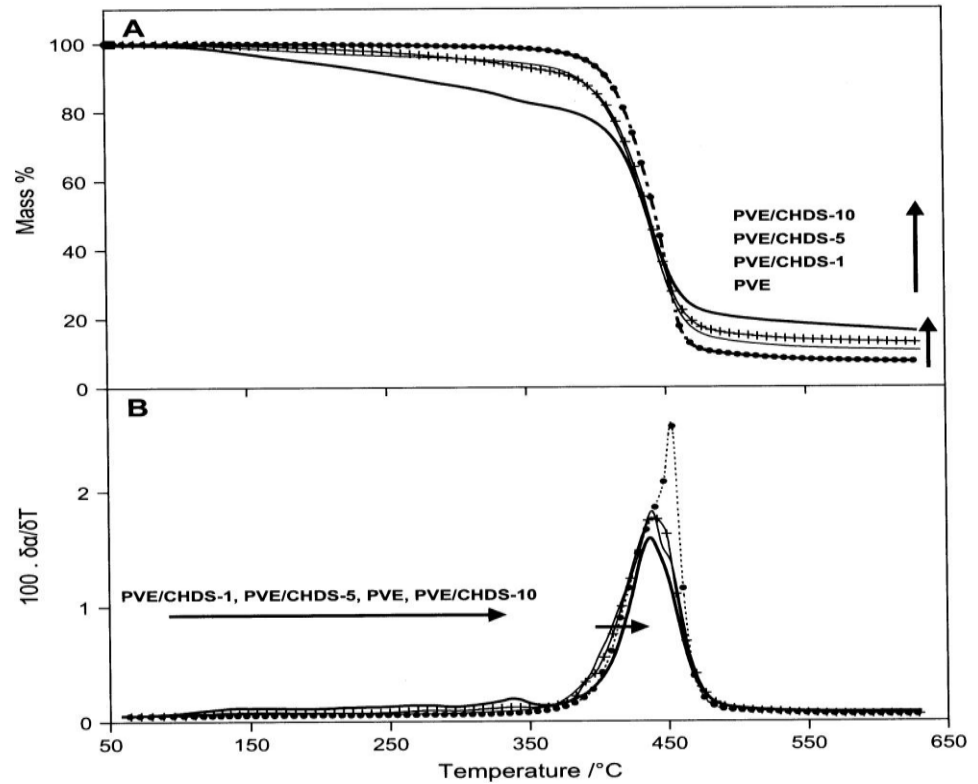

Polymer Degradation and Stability, Vol. 91, No. 8 (August 2006): pg. 1781-1790. DOI. This article is (C) Elsevier and permission has been granted for this version to appear in e-Publications@Marquette. Elsevier does not grant permission for this article to be further copied/distributed or hosted elsewhere without the express permission from Elsevier. 
NOT THE PUBLISHED VERSION; this is the author's final, peer-reviewed manuscript. The published version may be accessed by following the link in the citation at the bottom of the page.

\section{Figure 6}

(A) Curves of mass loss differences for PVE composites at PVE/CHDS-1 (solid), PVE/CHDS-5 (hatched), PVE/CHDS-10 (bold) loadings as a function of degradation temperature. (B) DTA curves for pure PVE (dotted and dashed), PVE/CHDS-1 (solid), PVE/CHDS-5 (hatched), and PVE/CHDS-10 (bold).

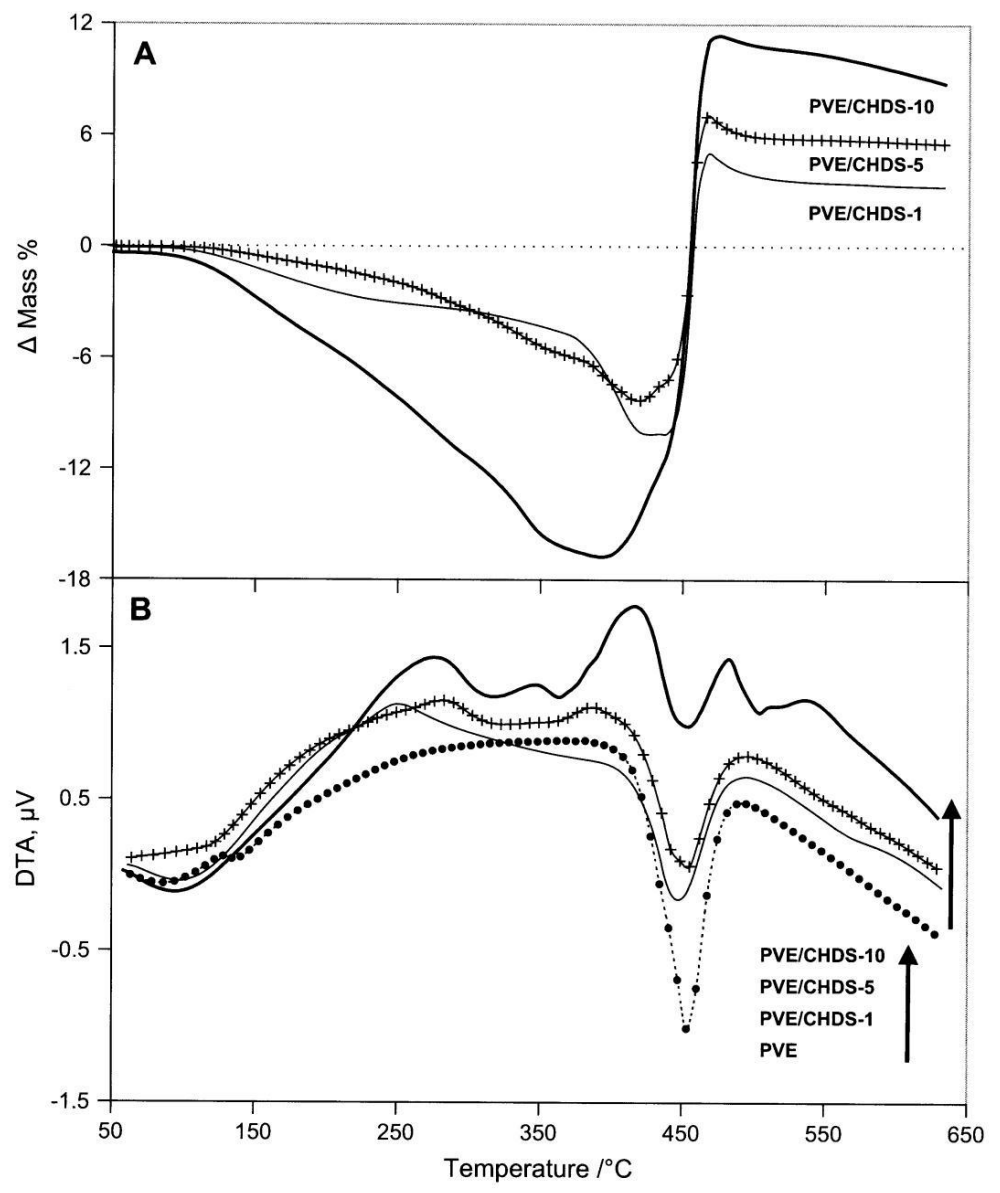

Polymer Degradation and Stability, Vol. 91, No. 8 (August 2006): pg. 1781-1790. DOI. This article is (c) Elsevier and permission has been granted for this version to appear in e-Publications@Marquette. Elsevier does not grant permission for this article to be further copied/distributed or hosted elsewhere without the express permission from Elsevier. 
NOT THE PUBLISHED VERSION; this is the author's final, peer-reviewed manuscript. The published version may be accessed by following the link in the citation at the bottom of the page.

\section{Figure 7}

Heat release rate curves for PVE (dotted and dashed), PVE/CHDS-1 (solid),

PVE/CHDS-5 (hatched), and PVE/CHDS-10 (bold) from cone calorimetry at $35 \mathrm{~kW} / \mathrm{m}^{2}$.

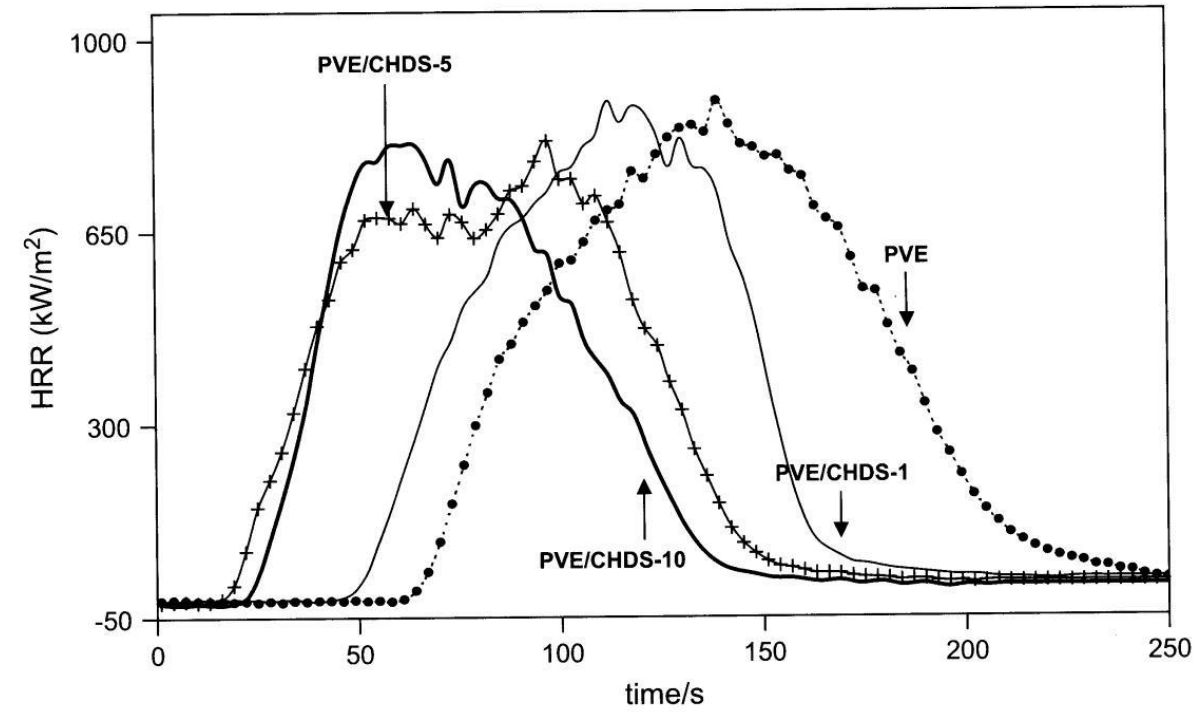

Figure 8

Percent reduction in total heat release $($ THR) vs. \% additive; observed reductions $(\bullet)$ and calculated reductions ( $(0)$. Calculated values assume no interaction between PVE and CHDS.

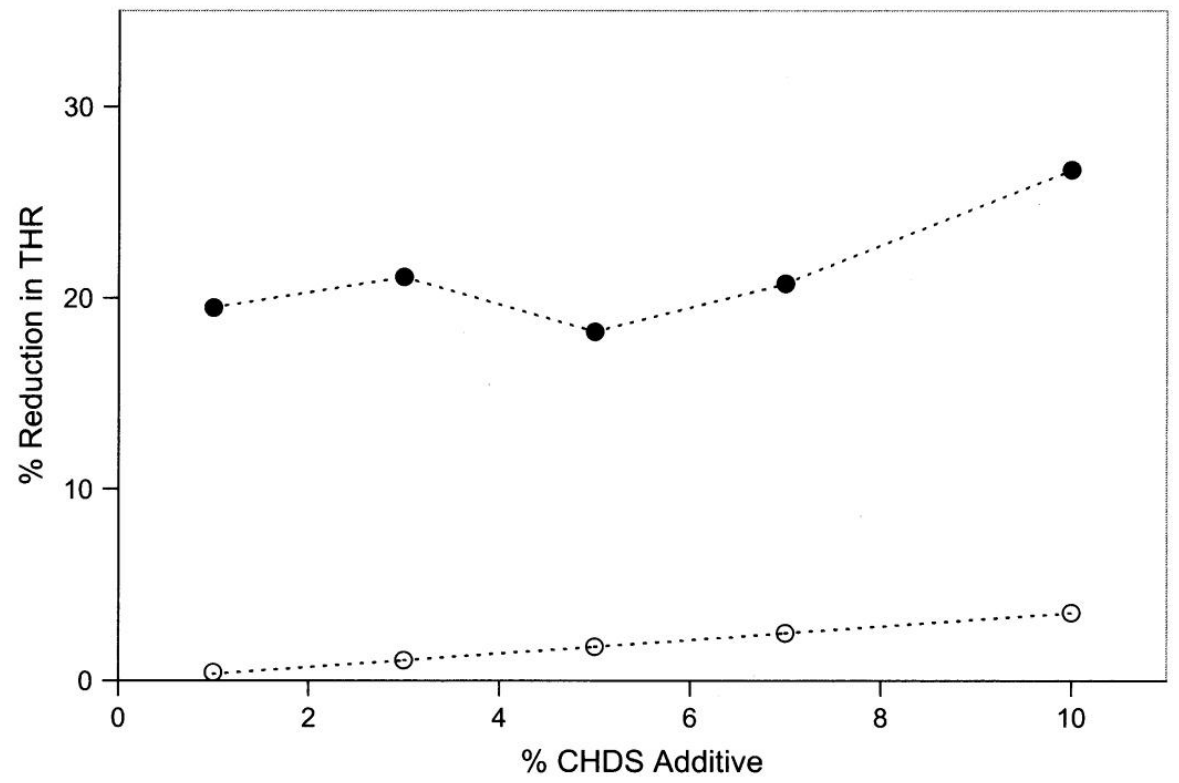

Polymer Degradation and Stability, Vol. 91, No. 8 (August 2006): pg. 1781-1790. DOI. This article is (C) Elsevier and permission has been granted for this version to appear in e-Publications@Marquette. Elsevier does not grant permission for this article to be further copied/distributed or hosted elsewhere without the express permission from Elsevier. 
NOT THE PUBLISHED VERSION; this is the author's final, peer-reviewed manuscript. The published version may be accessed by following the link in the citation at the bottom of the page.

\section{Figure 9}

XRD pattern of residue after heating PVE/CHDS-10 to indicated temperatures (250, $300,350,400,450$, and $650^{\circ} \mathrm{C}$ ) at $20^{\circ} \mathrm{C} / \mathrm{min}$ in TGA and from cone calorimetry (top trace) experiments. The XRD pattern for the PVE/CHDS-10 cone residue reveals the presence of $\mathrm{CuO}(\diamond), \mathrm{Cu} 2 \mathrm{O}(\Delta)$, metallic $\mathrm{Cu}(\mathbf{-})$ reflections. An unidentified phase $(+)$ is also observed in the TGA residue trace at $350^{\circ} \mathrm{C}$. Data are offset for clarity.

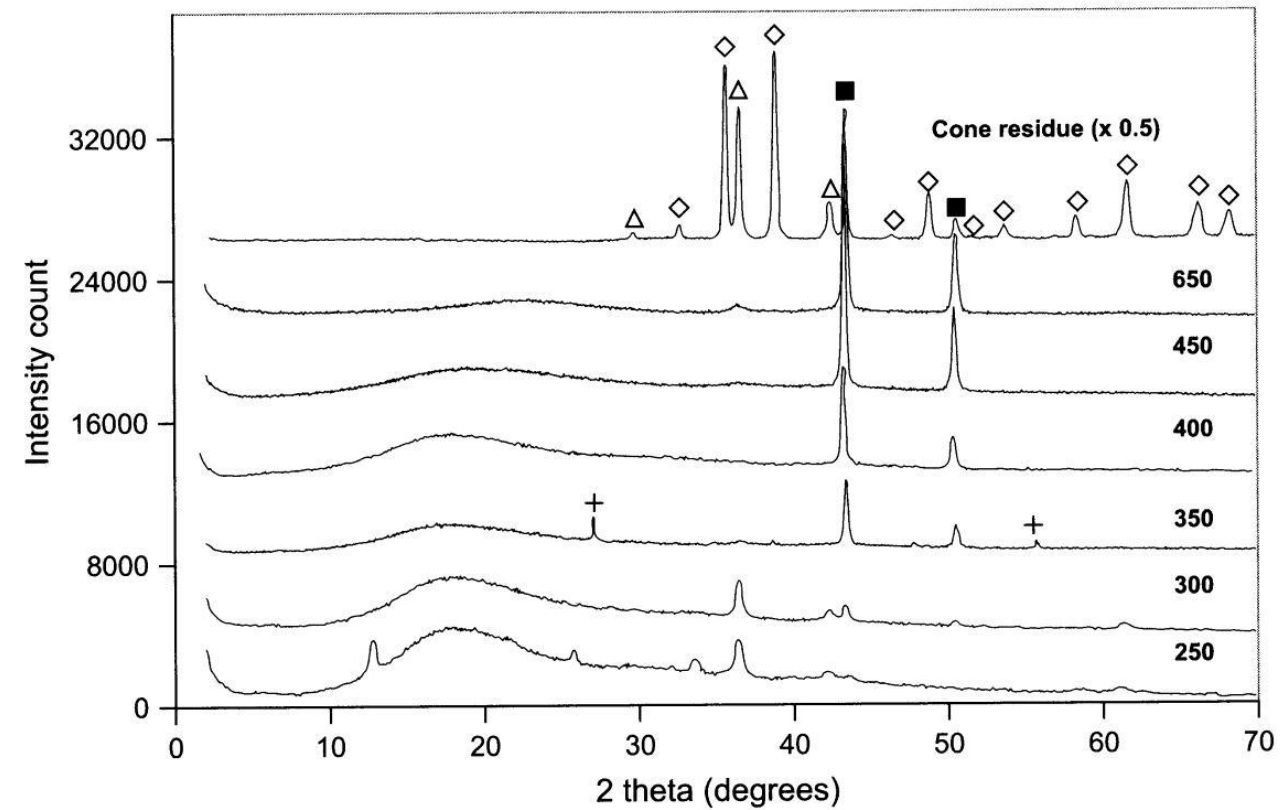

Figure 10

Fourier transform infrared (FTIR) traces for pure PVE, PVE/CHDS-10, and TGA residue of PVE/CHDS-10 heated to different temperatures are indicated in the plot. Data are offset for clarity but otherwise not scaled.

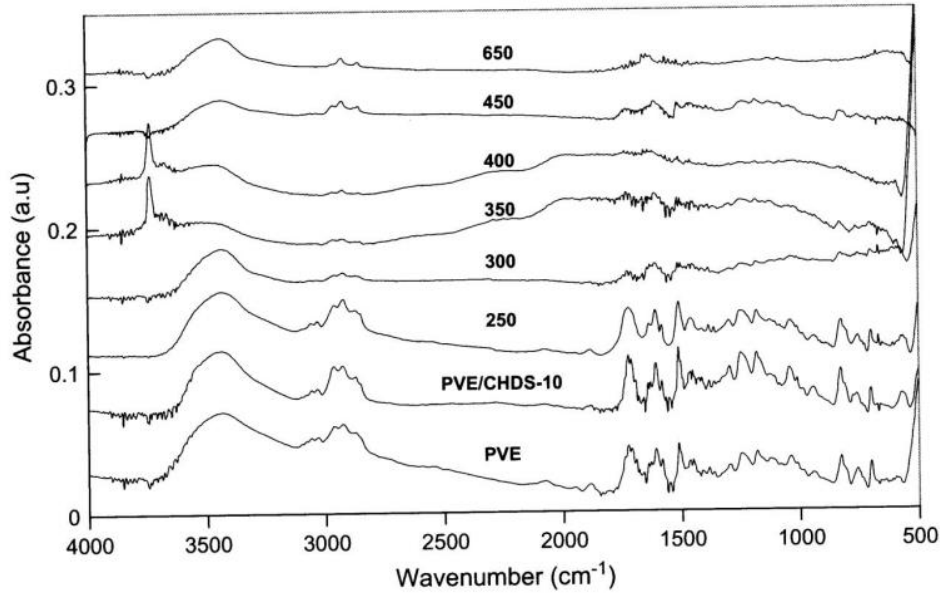

Polymer Degradation and Stability, Vol. 91, No. 8 (August 2006): pg. 1781-1790. DOI. This article is (C) Elsevier and permission has been granted for this version to appear in e-Publications@Marquette. Elsevier does not grant permission for this article to be further copied/distributed or hosted elsewhere without the express permission from Elsevier. 